\title{
THE GOVERNANGE IMPACT ON THE ROMANIAN TRADE FLOWS. AN AUGMENTED GRAVITY MODEL
}

\author{
Anca Tamaș ${ }^{1 *}$ and Dumitru Miron ${ }^{2}$ \\ 1) 2) Bucharest University of Economic Studies, Romania
}

Please cite this article as:

Tamaş, A. and Miron, D., 2021. The Governance

Impact on the Romanian Trade Flows. An

Augmented Gravity Model. Amfiteatru Economic,

23(56), pp. 276-289.

\section{Article History}

Received: 21 September 2020

Revised: 25 October 2020

Accepted: 25 November 2020

DOI: $10.24818 / \mathrm{EA} / 2021 / 56 / 276$

\begin{abstract}
The aim of this paper is to assess the impact of the quality of the Romanian governance process on the trade with EU countries between 2007 and 2018 using an augmented gravity model. The panel data method was used in order to cope with heteroskedasticity. The sample covers 12 years and includes 27 EU partner countries, chosen because Romania traded with all of them, therefore the zero problem was naturally solved. EViews 10 was used for regression. Cross-section SUR option was used.

The six governance indicators were used: voice and accountability, political stability, government effectiveness, regulatory quality, rule of law, control of corruption. The traditional variables (GDP, population, distance, common border, common language) had the expected signs and values. The following governance indicators proved to be significant for exporter countries: control of corruption with a negative influence, government effectiveness and political stability with a positive influence, Romanian political stability with a negative impact, Romanian rule of law with negative influence and Romanian regulatory quality with a positive impact, while the other indicators had a negative influence. The voice and accountability is not significant for exporter countries. An increase with $1 \%$ of the values of the government indicators would lead to significant increases of Romanian exports. The greatest impact on the exports would be the improvement of Romanian regulatory quality. The low quality of the Romanian institutions proved to be a major barrier in trading with EU countries. Therefore, an improvement of the Romanian institutions would unleash the trade between Romania and the other EU countries.
\end{abstract}

Keywords: economic governance, gravity model, governance indicators, trade flows

JEL Classification: F14, H11

* Corresponding author, Anca Tamaș - e-mail: anca.tamas@ rei.ase.ro 


\section{Introduction}

Governance is a key concept in social sciences that found its way into the mainstream of research only relatively lately. According to Bevir (2012), „Governance comprises all of the processes of governing - whether undertaken by the government of a state, by a market or by a network - over a social system (family, tribe, formal or informal organization, a territory or across territories) and whether through the laws, norms, power or language of an organized society". And from a different perspective, Hufty (2011) considered that governance is overlapping on "the processes of interaction and decisionmaking among the actors involved in a collective problem that lead to the creation, reinforcement, or reproduction of social norms and institutions". Usually, the concept of governance is used in phrases as good governance, democratic governance, efficient governance and their opposites.

Governance doesn't involve just the government, it includes civil-society actors and nowadays it means the public sector with the state actors and institutions, the private sector with the households and the companies and the nongovernmental sector with NGOs. The meaning of the concept of governance evolved from control and domination to descentralization and relational management, "control and domination" and governance with "descentralization and relational management".

This paper uses an augmented gravity model, meaning that along with the classical variables traditonally used in the gravity model (GDP, population, geographical distance) and the dummy variables (common border and common language), the authors considered other specific variables, like the Schengen membership the the six governance indicators: voice and accountability, political stability, government effectiveness, regulatory quality, rule of law, control of corruption.

The paper aims to highlight the most relevant tools and mechanisms of the multi-level governance that might be involved at the public policies level, with a suplimentary stress on the improvement process regarding the quality of the Romanian institutions impact on the trade flows.

The paper is structured as follows: the reviewing of the most significant studies in the area, focusing on the gravity model and its aplication in the economic governance field, during 2007-2018; the assessment of the way the new economic governance principles were internalized, between 2007-2018, based methodologically on the six governance indicators and on Romania's performance on these indicators. The research methodology - two models were tested, one for Romanian imports and one for Romanian exports, with two options each, with all variables or with the exporters variables only, followed by results and discussions.

\section{Literature review}

Adapting a law from Physics to Social or Economic Sciences is neither handy nor does it happen all the time. But it happened in 1962, when Jan Tinbergen decided to use the Newton's old law of gravity to analyse the dynamic and structure of trade flows. Newton's law stated that the attraction forces between two particles are directly proportional with their masses and inversely proportional with the square of the distance between them. In Tinbergen's vision, the trade flows between two countries are positively influenced by their 
economic sizes and negatively influenced by the geographic distance between them. When Tinbergen presented his brilliant intuition, he offered no theoretical background, but even so, the gravity model proved to be a successful empirical model. Among the most preeminent researchers who applied this methodological tool were Pöyhönen (1963), Pulliainen (1963) and Linnemann (1966). The first theoretical foundation of the model was the one of Anderson (1979), which was based on the Armington assumption, that goods from different regions are imperfect substitutes. Anderson's work was followed by the remarkable contributions of Bergstrand (1985), Deardorff (1998), Egger (2002), van Bergeijk and Brakman (2011) etc. In parallel with the theoretical studies, a lot of empirical studies proved that the gravity model is still the most successful model to explain the trade flows, in that way the model grew from an intellectual orphan (Anderson, 2010) into a workhorse, a toolkit and a cookbook (Head and Mayer, 2014).

The variables used in the gravity model initially were the GDP of the countries involved in bilateral trade connections and the distance between their capital cities as a proxy for the transport costs, but soon after other explanatory variables were added to the model, the most used ones being the common border, the common language, the colonial links (the actual or historical links between a country and a present or former colony) and the membership of the Free Trade Agreement (FTA).

Aron (2000) showed that when the property rights and the rule of law are not reliable, the transaction costs are much higher. In 2002, the first institutional variables were added to the gravity model by Anderson and Marcouiller, who proved that the quality of the institutions in the trading countries significantly affected the trade flows.

Kaufman et al. (2002) constructed a base of six indicators of perceived institutional quality in order to study the effect of good governance on the trade flows. A methodological architecture with which the quality of governance can be quantified and consists of six indicators (voice and accountability, political stability, government effectiveness, regulatory quality, rule of law and control of corruption) was developed by Kaufmann, Kraay and Mastruzzi (2004).

De Groot et al (2003) showed that the countries with poor institutions tend to trade more with similar countries and Jansen and Nordås (2004) proved that the domestic institutions had a positive and significant impact on the bilateral trade. Ranjan and Lee (2007) found out that institutions affect bilateral trade flows.

Kucharcukova et al (2010) proved that the low quality of institutional landscape in the countries of South-Eastern Europe was for a while an important barrier to their European integration and if these countries would have the same institutional quality as the EU countries, the trade will increase by $150 \%$. Bilgin et al (2017) found out that a large divergence in the effectiveness of the institutions reduce the bilateral trade.

Improvements in five out of six governance indicators would increase exports from Middle East and North Africa (MENA) countries, although a better quality of the institutions in the receiving countries would not affect the MENA EXPORTS. The same level of the regulatory quality and of the rule of law of MENA countries and their trading partners would increase the MENA exports (Martínez-Zarzoso and Márquez-Ramos, 2019). Good governance reduces the transaction costs of the trade mainly between high income countries (Setyastuti, 2018). 
According to Kaufman et al (2004), the governance means the traditions and the institutions by which the authority in a country is exercised. This term includes:

- Thprocess by which governments are selected, monitored and replaced, measured by the indicators: Voice and Accountability, Political Stability and Absence of Violence / Terrorism

- The capacity of the government to effectively formulate and implement sound policies, measured by the indicators Government Effectiveness and Regulatory Quality

- The respect of citizens and state for the institutions which govern economic and social interactions among them, measured by the indicators Rule of Law and Control of Corruption

The meaning of the six indicators of governance, according to the Worldwide Governance Indicators is given below:

- Voice and Accountability - the perception of the extent to which the citizens of a country are able to participate in the process of designating the deliberative and executive bodies and holding it accountable for the government's actions, it also involves the freedom of expression, the freedom of association and a free media.

- Political Stability and Absence of Violence / Terrorism - the perceptions of the likelihood that the government could be destabilized or overthrown by violent means, including politically motivated violence and terrorism, it also involves excesses of violence against people or possessions.

- Government Effectiveness - the perceptions of the quality of public and civil services and the degree of independence of these services from political pressures, the quality of policies formulation and policies implementation and the credibility of the government's commitment to these policies, it is a measure for the quality of the government input.

- Regulatory Quality - the perceptions of the ability of the government to prepare and implement sound macroeconomic and sectorial policies and regulations which allow and promote private sector development.

- Respecting the Principles of Rule of Law - the perceptions of the extent to which economic actors have confidence and abide by the rules of society, the quality of the contract enforces, the property rights, the police, the courts, the likelihood of crime and violence, it measures the quality of the legal system.

- Control of Corruption - the perceptions of the extent to which the public power is exercised for private gain, including different forms of corruption, it represents the degree in which the state is captured by the elites and private interests, it also includes the lawless or unfair behaviour in public-private interactions.

\section{The governance in Romania in the period 2007- 2018}

Next, we will analyze Romania's performance on the 6 governance indicators using the World Governance Index, which has values between -2.5 and 2.5, these indices being established annually in over 200 countries. These performances are mentioned in table no. 1 , which specifies the highest, respectively the lowest score of Romania for each indicator and the year in which it was obtained, respectively the best and the lowest ranking of Romania in the EU for each indicator. 
Table no. 1: The Romanian governance performances 2007-2018

\begin{tabular}{|c|c|c|c|c|}
\hline Indicator & $\begin{array}{l}\text { The lowest } \\
\text { score / year }\end{array}$ & $\begin{array}{l}\text { The highest } \\
\text { score / year }\end{array}$ & $\begin{array}{c}\text { The lowest rank / } \\
\text { year }\end{array}$ & $\begin{array}{c}\text { The highest } \\
\text { rank / } \\
\text { year }\end{array}$ \\
\hline $\begin{array}{c}\text { Voice and } \\
\text { accountability }\end{array}$ & $\begin{array}{c}0.31 \\
(2013)\end{array}$ & $\begin{array}{c}0.52 \\
(2017)\end{array}$ & $\begin{array}{c}28 \\
(2007,2009-2013)\end{array}$ & $\begin{array}{c}25 \\
(2015-2017)\end{array}$ \\
\hline $\begin{array}{l}\text { Political stability and } \\
\text { absence } \\
\text { of violence / terrorism }\end{array}$ & $\begin{array}{c}0.05 \\
(2014)\end{array}$ & $\begin{array}{c}0.36 \\
(2009)\end{array}$ & $\begin{array}{c}27 \\
(2007,2008,2014, \\
2017,2018)\end{array}$ & $\begin{array}{c}22 \\
(2009)\end{array}$ \\
\hline $\begin{array}{l}\text { Government } \\
\text { effectiveness }\end{array}$ & $\begin{array}{c}-0.36 \\
(2009) \\
\end{array}$ & $\begin{array}{c}-0.03 \\
(2014) \\
\end{array}$ & $\begin{array}{c}28 \\
(2007-2018)\end{array}$ & $\begin{array}{c}28 \\
(2007-2018)\end{array}$ \\
\hline Regulatory quality & $\begin{array}{c}-0.11 \\
(2008)\end{array}$ & $\begin{array}{c}-0.03 \\
(2018) \\
\end{array}$ & $\begin{array}{c}27 \\
(2007-2015) \\
\end{array}$ & $\begin{array}{c}24 \\
(2017-2018) \\
\end{array}$ \\
\hline Rule of law & $\begin{array}{c}0.45 \\
(2018)\end{array}$ & $\begin{array}{c}0.66 \\
(2011)\end{array}$ & $\begin{array}{c}27 \\
(2007-2010,2018)\end{array}$ & $\begin{array}{c}24 \\
(2011)\end{array}$ \\
\hline Control of corruption & $\begin{array}{c}-0.26 \\
(2009,2012)\end{array}$ & $\begin{array}{c}-0.02 \\
(2015,2016)\end{array}$ & $\begin{array}{c}28 \\
(2009,2010,2012)\end{array}$ & $\begin{array}{c}25 \\
(2013-2017)\end{array}$ \\
\hline
\end{tabular}

Source: Authors' estimates based on the data from World Bank, 2020

The data in Table no. 1 shows the poor performances of the Romanian governance between 2007 and 2018, one of the worst performances among the EU countries and the low progress made in this period, proved by the modest Romanian ranks, the best rank was $22^{\text {th }}$ out of $28 \mathrm{EU}$ countries at political stability and the absence of violence/terrorism that happened more than 10 years ago (2009). The worst position was on goverment effectiveness, where Romania was not able to move forward from the last position.

Figure no. 1 represents the evolution of the Romanian trade values at world level and at EU level in 2007-2018 period. One can notice that in both cases the Romanian imports are greater than the exports.

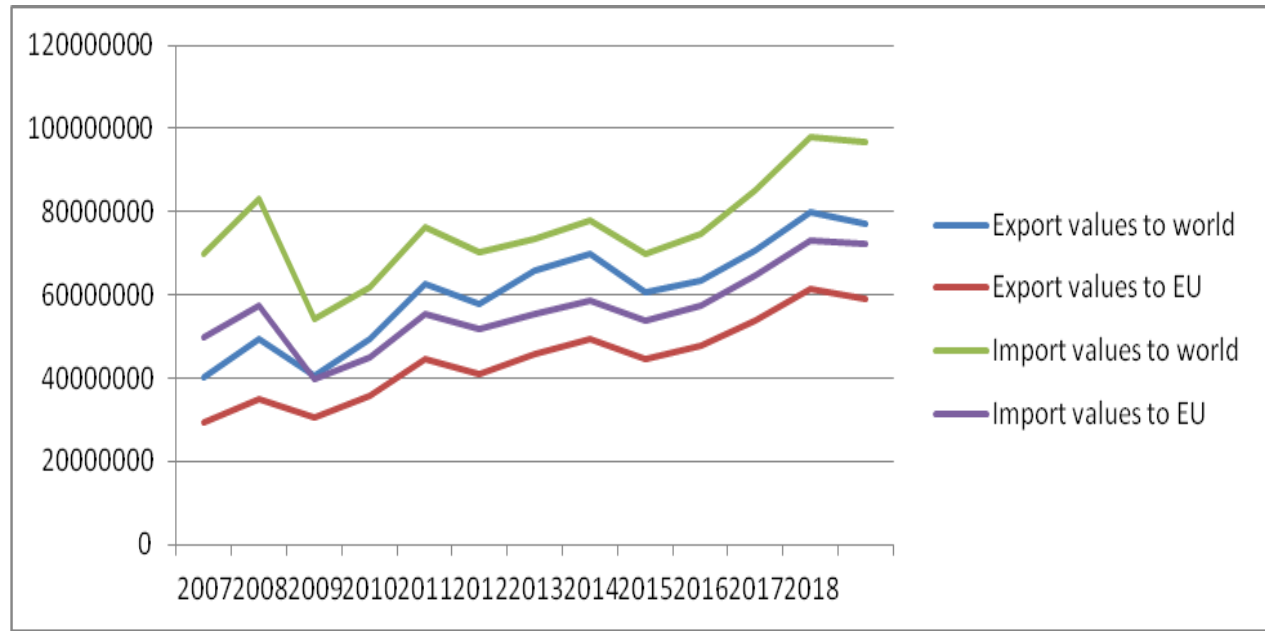

Figure no. 1: The evolution of the Romanian trade values to world and to EU between 2007-2018

Source: International Trade Centre, 2020 
After the year 2011, the Romanian imports and exports had a growing trend, the imports value grew by $140 \%$ in 2019 compared to 2007 , while the exports value doubled in the same period at world level, as well as at EU level too. Trade balance remained negative all the same since the imports outpaced the exports. On average, $73 \%$ of the Romanian imports were from EU countries and $74 \%$ of the Romanian exports went to EU countries, as seen in Figure no. 2.

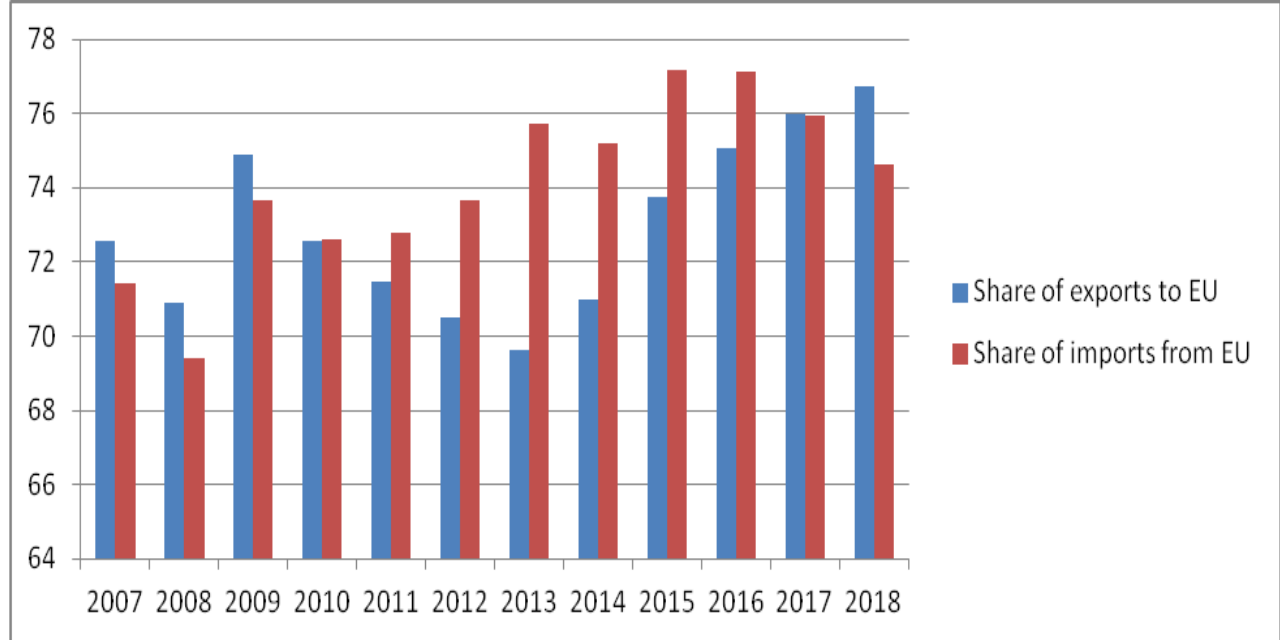

Figure no. 2: The share of the Romanian trade with the EU countries between 2007 and 2018

Source: International Trade Centre, 2020

\section{Research methodology}

The aim of this paper is to assess the impact of the quality of the Romanian governance process on the trade with the EU countries between 2007 and 2018 using an augmented gravity model.

The EU countries were chosen having in mind that: in the considered period, most of the Romanian trade was with these countries, Romania traded with all EU countries, that way the zero problem of the gravity model was naturally solved ${ }^{\dagger}$, therefore there will be no loss of information applying the model. The period was chosen for important reasons as well, it is after 2007, the year of Romania's joining EU. Therefore, the trade barriers were at the lowest level possible within EU trade, so the trade barriers because of governance impact do not interfere with other kind of trade barriers. The year 2018 was chosen because WGI cover the period 1996-2018 for now.

An augmented gravity model was used, beside the traditional variables: GDP and population of Romania and of the partner countries, the distance between the trading

$\dagger$ The zero problem appears when, in certain periods of time, certain pairs of countries don't have trade flows and this leads to the impossibility of using logarithms. 
countries and the traditional dummy variables $*$, common border and common language, there were added variables for the six governance indicators for Romania and for the partner countries and a dummy variable for Schengen membership of the partner countries. Imports and exports were separately considered as dependent variables, as the previous studies suggested impacts of governance on import flows and on the export flows (Martínez-Zarzoso and Márquez-Ramos, 2019). The impact of GDP of the trading partner is expected to be greater compared to the impact of GDP of Romania for exports (Binh et al, 2013), the same results for imports as well (Alam et al, 2009). The larger the partner country GDP is, the less will be the distance effect on trade (Marimoutou et al, 2010). The distance coefficient should be close to -1 (Chaney, 2011). The common border effect on the trade flows should be greater than the common language effect (Linders et al, 2005). Schengen membership of the trading country should have a positive effect on trade (Felbermayr et al., 2018).

The panel data approach was considered for estimation of the gravity equation (Baltagi, Egger and Pfaffermary, 2015; Egger and Staub, 2015) and EViews10 was used to perform the regression. Cross-section SUR option was used because EViews estimates a feasible GLS specification correcting for heteroskedasticity and for contemporaneous correlation.

Two models were tested, one for the Romanian exports and one for Romanian imports, each of them with two options, with all variables and with exporters' variables. All variables mean all traditional variables of the gravity model, GDP and population of the trading countries, the distance between the two countries, common border and common language, Schengen membership and the six governance indicators for the two countries. Exporters' variables mean all the above mentioned traditional variables and the governance indicators referring to the exporting country. For Romanian exports, that will be Romanian governance indicators and for Romanian imports, that will be indicators for the other $27 \mathrm{EU}$ countries.

The gravity equations were:

LNEXPVAL $_{t}=a_{0}+a_{1}$ LNGDPP $_{t}+a_{2}$ LNGDPR $_{t}+\mathrm{a}_{3}$ LNDIST $+\mathrm{a}_{4}$ LNPOPP $_{t}+\mathrm{a}_{5}$ LNPOPR $_{t}+$ $\mathrm{a}_{6} \mathrm{CB}+\mathrm{a}_{7} \mathrm{CL}+\mathrm{a}_{8}$ Schengen $+\mathrm{a}_{9} \mathrm{CC}{ }_{\mathrm{t}}+\mathrm{a}_{10} \mathrm{CCR}_{\mathrm{t}}+\mathrm{a}_{11} \mathrm{GE}_{\mathrm{t}}+\mathrm{a}_{12} \mathrm{GER}_{\mathrm{t}}+\mathrm{a}_{13} \mathrm{PS}_{\mathrm{t}}+\mathrm{a}_{14} \mathrm{PSR}_{\mathrm{t}}+$ $\mathrm{a}_{15} \mathrm{RL}_{\mathrm{t}}+\mathrm{a}_{16} \mathrm{RLR}_{\mathrm{t}}+\mathrm{a}_{17} \mathrm{RQ}_{\mathrm{t}}+\mathrm{a}_{18} \mathrm{RQR}_{\mathrm{t}}+\mathrm{a}_{19} \mathrm{VA}_{\mathrm{t}}+\mathrm{a}_{20} \mathrm{VAR}_{\mathrm{t}}+\varepsilon_{1}$

LNEXPVAL $_{t}=b_{0}+b_{1}$ LNGDPP $_{t}+b_{2}$ LNGDPR $_{t}+b_{3}$ LNDIST $+b_{4}$ LNPOPP $_{t}+b_{5}$ LNPOPR $_{t}$ $+b_{6} C B+b_{7} C L+b_{8}$ Schengen $+b_{9} C R_{t}+b_{10}$ GER $_{t}+b_{11}$ PSR $_{t}+b_{12}$ RLR $_{t}+b_{13}$ RQR $_{t}+$ $\mathrm{b}_{14} \mathrm{VAR}_{\mathrm{t}}+\varepsilon_{2}$

LNIMPVAL $_{\mathrm{t}}=\mathrm{c}_{0}+\mathrm{c}_{1} \mathrm{LNGDPP}_{\mathrm{t}}+\mathrm{c}_{2} \mathrm{LNGDPR}_{\mathrm{t}}+\mathrm{c}_{3} \mathrm{LNDIST}+\mathrm{c}_{4} \mathrm{LNPOPP}_{\mathrm{t}}+\mathrm{c}_{5} \mathrm{LNPOPR}_{\mathrm{t}}+$ $\mathrm{c}_{6} \mathrm{CB}+\mathrm{c}_{7} \mathrm{CL}+\mathrm{c}_{8}$ Schengen $+\mathrm{c}_{9} \mathrm{CC}_{\mathrm{t}}+\mathrm{c}_{10} \mathrm{CCR}_{\mathrm{t}}+\mathrm{c}_{11} \mathrm{GE}_{\mathrm{t}}+\mathrm{c}_{12} \mathrm{GER}_{\mathrm{t}}+\mathrm{c}_{13} \mathrm{PS}_{\mathrm{t}}+\mathrm{c}_{14} \mathrm{PSR}_{\mathrm{t}}+$ $c_{15} R_{t}+c_{16} R L R_{t}+c_{17} R Q_{t}+c_{18} R Q R_{t}+c_{19} V_{t}+c_{20} V_{A R}+\varepsilon_{3}$

LNIMPVAL $_{\mathrm{t}}=\mathrm{d}_{0}+\mathrm{d}_{1}$ LNGDPP $_{\mathrm{t}}+\mathrm{d}_{2}$ LNGDPR $_{\mathrm{t}}+\mathrm{d}_{3}$ LNDIST $+\mathrm{d}_{4} \mathrm{LNPOPP}_{\mathrm{t}}+\mathrm{d}_{5}$ LNPOPR $_{\mathrm{t}}$ $+\mathrm{d}_{6} \mathrm{CB}+\mathrm{d}_{7} \mathrm{CL}+\mathrm{d}_{8}$ Schengen $+\mathrm{d}_{9} \mathrm{CC}_{\mathrm{t}}+\mathrm{d}_{10} \mathrm{GE}_{\mathrm{t}}+\mathrm{d}_{11} \mathrm{PS}_{\mathrm{t}}+\mathrm{d}_{12} \mathrm{RL}_{\mathrm{t}}+\mathrm{d}_{13} \mathrm{RQ}_{\mathrm{t}}+\mathrm{d}_{14} \mathrm{VA}_{\mathrm{t}}+$ $\varepsilon_{4}$

$\$$ The dummy variables take only values of 1 or 0,1 if the information is available for this country (in this case if the partner country has common border / common language with Romania) and 0 otherwise. 
The dependent variables are:

- LNEXPVALt is (the logarithm of) the Romanian export values to EU countries in year $\mathrm{t}$.

- LNIMPVALt is (the logarithm of) the Romanian import values from EU countries in year $\mathrm{t}$.

Both LNEXPVAL $\mathbf{t}_{\boldsymbol{t}}$ and LNIMPVAL $_{\boldsymbol{t}}$ are dependent variables, the data were collected from International Trade Centre - ITC (2020) database.

The independent variables are:

LNGDPP $_{\mathbf{t}}$ and LNGDPR $_{\mathbf{t}}$ are respectively the GDP of the partner country and the GDP of Romania in year $t$ and they are a measure of the market.

LNPOPP $_{\mathbf{t}}$ and LNPOPR $_{\mathbf{t}}$ are respectively the population of the partner country and the population of Romania in year $t$ and they are a measure of the market.

All four representing the market size are expected to have positive signs. The data for them were collected from World Bank database.

LNDIST is (the logarithm of) the distance between the capitals of Romania and the partner country, as a proxy for transport costs. It was calculated using the great circle formula and it is expected to have negative signs.

The dummy variables used were:

CB is the common border, which takes the value 1 if Romania and the trading country share a common border and 0 otherwise. CL is the common language, which takes the value 1 if in Romania and in the partner country the same language is spoken by an important part of the population and 0 otherwise. Schengen takes the value 1 if Romania's trading partner is a Schengen country and 0 otherwise. All three dummy variables are expected to have positive signs.

$\mathbf{C C}_{\mathbf{t}}$ and $\mathbf{C C R}$ are the indices for the control of corruption indicator for the partner country and Romania respectively in year t. GEt and $\mathbf{G E R}_{\mathbf{t}}$ are the indices for government effectiveness indicator for the partner country and Romania respectively in year $\mathbf{t}$. $\mathbf{P S}_{\mathbf{t}}$ and PSR $_{\mathbf{t}}$ are the indices for political stability indicator for the partner country and Romania respectively in year t. RLt and $\mathbf{R L R}_{\mathbf{t}}$ are the indices for rule of law indicator for the partner country and Romania respectively in year t. $\mathbf{R} \mathbf{Q}_{\mathbf{t}}$ and $\mathbf{R} \mathbf{Q} \mathbf{R}_{\mathbf{t}}$ are the indices for regulatory quality indicator for the partner country and Romania respectively in year $t$. $\mathbf{V A} \mathbf{A}_{\mathbf{t}}$ and $\mathbf{V A} \mathbf{R}_{\mathbf{t}}$ are the indices for voice and accountability indicator for the partner country and Romania respectively in year $\mathrm{t}$. Year $\mathrm{t}$ is each year from 2007 to 2018.

$\mathbf{a}_{\mathbf{i}}$ and $\mathbf{c}_{\mathbf{i}}$ are coefficients, where $\mathrm{i}$ takes natural values from 0 to 20 . $\mathbf{b}_{\mathbf{j}}$ and $\mathbf{d}_{\mathbf{j}}$ are coefficients, where $\mathrm{j}$ takes natural values from 0 to 14 . $\boldsymbol{\varepsilon}_{\mathbf{k}}$ is the error term, where $\mathrm{k}$ takes the values $1,2,3,4$. The error term can be decomposed in three terms, one for country specific errors, one for time specific errors and one for time and country errors.

\section{Results and discussion}

Table no. 2 presents the synoptic influence of all the above mentioned variables on Romanian imports and exports in 2007-2018 period. 
Table no. 2: The results for Romanian exports (dependent variable LNEXPVAL) and Romanian imports (dependent variable LNIMPVAL)

\begin{tabular}{|c|c|c|c|c|}
\hline \multirow[t]{2}{*}{ Coefficient } & \multicolumn{2}{|c|}{ Exports } & \multicolumn{2}{|c|}{ Imports } \\
\hline & All variables & $\begin{array}{r}\text { Exporters' } \\
\text { variables }\end{array}$ & All variables & $\begin{array}{r}\text { Exporters' } \\
\text { variables }\end{array}$ \\
\hline $\mathrm{C}$ & $-122.47^{*}$ & $-108.29^{*}$ & $-507.58^{*}$ & $-226.11^{*}$ \\
\hline LNGDPP & $0.48^{*}$ & $0.52^{*}$ & $1.19^{*}$ & $1.19^{*}$ \\
\hline LNGDPR & $1.67^{*}$ & $1.67^{*}$ & $2.58^{*}$ & $1.14^{*}$ \\
\hline LNDIST & $-1.06^{*}$ & $-1.13^{*}$ & $-1.04^{*}$ & $-1.03^{*}$ \\
\hline LNPOPP & $0.60^{*}$ & $0.50^{*}$ & -0.15 & -0.15 \\
\hline LNPOPR & $4.46^{* *}$ & $3.58^{* * * *}$ & $25.55^{*}$ & $11.11^{*}$ \\
\hline $\mathrm{CB}$ & 0.51 & 0.34 & $0.85^{\text {*** }}$ & $0.83^{\text {*** }}$ \\
\hline $\mathrm{CL}$ & 0.44 & 0.38 & $0.57^{* * * *}$ & $0.58^{* *}$ \\
\hline Schengen & 0.20 & $0.36^{* * *}$ & 0.28 & 0.28 \\
\hline $\mathrm{CC}$ & -0.06 & - & $-0.48^{* *}$ & $-0.44^{*}$ \\
\hline CCR & $-0.60^{\text {***** }}$ & $-0.77^{*}$ & 0.07 & - \\
\hline GE & 0.10 & - & $0.18^{* *}$ & $0.19^{* * *}$ \\
\hline GER & 0.04 & 0.13 & -0.17 & - \\
\hline PS & 0.04 & - & $0.20^{*}$ & $0.22^{*}$ \\
\hline PSR & -0.78 & $-0.70^{*}$ & $-0.39^{*}$ & - \\
\hline RL & -0.05 & - & 0.05 & -0.01 \\
\hline RLR & -0.27 & $-0.35^{* * *}$ & 0.03 & - \\
\hline RQ & -0.06 & - & $-0.36^{*}$ & $-0.35^{*}$ \\
\hline RQR & $1.91^{*}$ & $1.88^{*}$ & $1.58^{*}$ & - \\
\hline VA & $0.31^{* * * *}$ & - & $0.63^{*}$ & $0.63^{*}$ \\
\hline VAR & -0.04 & 0.09 & $-0.78^{* *}$ & - \\
\hline R Squared & 0.76 & 0.76 & 0.78 & 0.77 \\
\hline
\end{tabular}

Notes: * significant at $1 \%$ level; **significant at $5 \%$ level; $* * *$ significant at $10 \%$ level

GDP of both partners (Romania and the partner country) had a positive influence both on the exports and on the imports, the values for the coefficients of the GDP of the exporter country were greater than the ones for the coefficients of the GDP of the importer country, except for the imports with all variables.

For Romanian exports, the population of the partner countries, as well as the population of Romania, had a positive impact. But for Romanian imports, the impact of population of the trading country is not statistically significant and the Romanian population had a positive influence.

The coefficients of distance had the expected negative signs and values, the values for exports were slightly greater compared to the ones for imports.

Common border and common language were significant for imports, but not for exports, while Schengen membership of the partner country had the expected positive sign, but it was significant only for exports with exporters' variables.

Control of corruption of the partner country was significant for Romanian imports and control of corruption of Romania was significant for the exports. All the signs were negative for this indicator. Government effectiveness of the trading country is significant for imports and it is not significant for exports. Political stability of the partner country is significant for imports, but not for exports and it has a positive influence, while the political 
stability of Romania is not significant for exports with all variables and it is significant in the other cases, with a negative influence. Rule of law of the trading partner is not significant, as for Romanian rule of law, it matters in one case and it has a negative sign. Regulatory quality of the partner countries matters for imports and the one for Romania matters for imports and exports as well. Voice and accountability of the partner country is significant for exports and imports and voice and accountability of Romania is significant for imports only.

The following governance indicators proved to be significant for exporter countries: control of corruption with a negative influence, government effectiveness and political stability with a positive influence, Romanian political stability with a negative impact, Romanian rule of law with negative influence and Romanian regulatory quality with a positive impact, while the other indicators had a negative influence. The voice and accountability is not significant for exporter countries.

To estimate which impact would have the improvement of the Romanian governance indicators with $1 \%$ on the Romanian exports, the exponential value of the Romanian governance coefficients was computed. (Table no. 3)

Table no. 3: Expected increase of the Romanian exports in case of the Romanian governance improvement with $1 \%$

\begin{tabular}{|c|c|c|c|c|c|c|}
\hline Indicator & $\begin{array}{c}\text { Corruption } \\
\text { control }\end{array}$ & $\begin{array}{c}\text { Government } \\
\text { effectiveness }\end{array}$ & $\begin{array}{c}\text { Political } \\
\text { stability }\end{array}$ & $\begin{array}{c}\text { Rule of } \\
\text { law }\end{array}$ & $\begin{array}{c}\text { Regulatory } \\
\text { quality }\end{array}$ & $\begin{array}{c}\text { Voice and } \\
\text { accountability }\end{array}$ \\
\hline $\begin{array}{c}\text { Expected exports' } \\
\text { increase }\end{array}$ & $46 \%$ & $113 \%$ & $49 \%$ & $70 \%$ & $655 \%$ & $109 \%$ \\
\hline
\end{tabular}

As can be seen, the improvement of any of the 6 governance indicators by $1 \%$ would lead to an estimated significant increase in Romanian exports. The biggest impact would have the quality of regulations, the improvement by only $1 \%$ of the quality of regulations would lead to a huge increase, not less than $655 \%$, of Romanian exports. Significant increases in Romanian exports, over $100 \%$, would also occur in the case of improving indicators government efficiency (113\%) and voice and responsibility (109\%). Improving the quality of the other 3 governance indicators would lead to smaller, but no less important, increases in Romanian exports: $70 \%$ in the case of the rule of law, $49 \%$ in the case of political stability and $46 \%$ in the case of corruption control.

In order to narrow the heterogeneity of data, only the Romanian exports and the Romanian imports were studied. To avoid the zero problem of the gravity model, the trading countries considered were EU countries only. This particular way of chosing the partner countries had the advantage of lowering the multi resistance factor, therefore the main trade barriers effect was because of governance indicators.

For the traditional variables, the results were consistent with previous studies (Tinbergen (1962); Pöyhönen (1963); Pulliainen (1963); Linnemann (1966)). The GDP of Romania and of the partner countries was considered in PPP (Purchasing Power Parity) standards to avoid the co-linearity problems. The GDP of receiving countries represents the demand and the absolute import power, while the GDP of the exporter represents the production potential. The GDP impact of the partner countries was 0.52 for Romanian exports and 1.19 for Romanian imports, while the Romanian GDP influence on the exports was 1.76 and on the imports 1.14. The results were consistent with the ones of Bergstrand (1990). 
The population could be seen as a proxy for the market size of the receiving country. The population of the trading partners has a similar influence (0.50) with their GDP on the Romanian exports and no influence on the Romanian imports. Romanian population had a strong positive influence on the exports and even a larger influence on the imports. The results for the population of the trading countries are in line with the findings of Walsh (2006).

The distance between Romania and the trading countries has a negative impact both on exports and on imports, coefficients were close to -1 , confirming the results of Deardorff (1998).

Common border and common language were not found to be significant for exports, yet significant for imports and the coefficients were slightly higher than the ones in the previous studies (Helpman and Krugman, 1985), 0.8 instead of 0.6 for the first one and 0.5 instead of 0.4 for the last one. The Schengen membership of the partner countries had a small positive influence on the exports and no influence on the imports.

The most powerful positive influence of the six governance indicators on exports, as well as on imports, was the regulatory quality of Romania, for exports the regulatory quality had a greater impact than the Romanian GDP. The same indicator of the trading countries had no influence on the exports and a small negative influence on the imports. The results are in line with the findings of Martínez-Zarzoso and Márquez-Ramos (2019).

The Romanian rule of law had a negative impact on exports and no impact on imports, similar with findings of Aron (2000). Apart from the regulatory quality, the poor quality of the Romanian governance, revealed by the low values of the indicators, led to a negative impact or an insignificant influence on the trade flows, in contradiction with the findings of Jansen and Nordås (2004).

For Romanian exports, the lowest impact was the one of government effectiveness and the Romanian voice and accountability. Rule of law, the Romanian government effectiveness and control of corruption had no significant influence on the Romanian imports. There was a large divergence on the impact of the governance indicators on Romanian exports and imports during 2007-2018, as confirmed by Bilgin et al (2017).

Romania should strive to improve the quality of institutions, which would increase the opportunity of trading with countries with better institutions, according to de Groot et al (2003) and to reduce the transaction costs, as proven by Setyastuti et al (2018). The low quality of the Romanian institutions proved to be a barrier in trading with EU countries, since one out of the six indicators had a positive significant influence on the trade flows, similar with the results of Kucharcukova et al (2010). Therefore, an improvement of the Romanian institutions would unleash the trade between Romania and the other EU countries.

\section{Conclusions}

An augmented gravity model was used, adding the governance indicators to the traditional trade determinants (GDP, population, distance, common border, common language, Schengen membership) (Anderson and Marcouiller, 2002; Dollar and Kraay, 2004). The framework for the quality of governance used in this paper is based on the six indicators introduced by Kaufmann et al. (2002, 2004) and developed by Khorana et al. (2014), Gylfason et al. (2015), namely voice and accountability, political stability, government effectiveness, regulatory quality, rule of law, control of corruption. 
Improving the quality of the Romanian institutions should be a clear priority of the authorities because, as proven, this would lead to the opportunity of trade with countries with better institutions (see results in Tabel no 3) (de Groot et al., 2003) and would reduce the transaction costs (Setyastuti et al., 2018). For the moment, the situation is far for being an ideal one, only one out of the six indicators of the Romanian governance has a positive influence on the trade flows, regulatory quality (see results in Table no 2) (Kucharcukova et al., 2010). All the other indicators of the Romanian governance have a negative influence on the trade flows. A major improvement of the quality of the Romanian institutions is needed to boost the trade between Romania and the other EU countries.

The practical implications of the article result from the impact of increasing the quality of the institutions on the Romanian exports. If the values of the governance indicators would grow with only $1 \%$, than Romanian exports would significantly grow as well.

The biggest impact on exports would be to improve the quality of regulations (huge potential increase - 655\%), followed by improved indicators of government efficiency and voice and responsibility (large potential increases - over 100\%) (see results in Table no. 3). According to the authors' knowledge, this is the first study on the impact of the governance indicators on the Romanian trade flows. The main limitation of this paper is that only the trade within the EU was considered. Further research should be considered to enlarge the base of the trading partners.

\section{References}

Alam, M., Uddin, G.S. and Taufique, K., 2009. Import Inflows of Bangladesh: the Gravity Model Approach. International Journal of Economics and Finance, [e-journal] 1(1), pp. 131-140. DOI: 10.5539/ijef.v1n1p131.

Anderson, J.E., 1979. A Theoretical Foundation for Gravity Equation. American Economic Review, 69(1), pp.106-16.

Anderson, J.E., 2010. The Gravity Model. The National Bureau of Economic Research (NBER), NBER Working Paper No. 16576. NBER Program(s): International Trade and Investment. DOI: $10.3386 /$ w16576.

Anderson, J.E. and Marcouiller, D., 2002. Insecurity and The Pattern Of Trade: An Empirical Investigation. Review of Economics and Statistics, [e-journal] 84(2), pp.342-352. DOI: 10.1162/003465302317411587.

Aron, J., 2000. Growth and Institutions: A Review of the Evidence. The World Bank Research Observer, 15(1), pp.99-135.

Baltagi, B.H., Egger, P. and Pfaffermary, M, 2015. Panel Data Gravity Models of International Trade. In: B. H. Baltagi ed., 2015. The Oxford Handbook of Panel Data. Oxford: Oxford University Press, pp. 608-641.

Bevir, M., 2012. Governance: A very short introduction. Oxford: Oxford University Press.

Bergstrand, J.H., 1985. The Gravity Equation in International Trade: Some Microeconomic Foundations and Empirical Evidence. Review of Economics and Statistics, [e-journal] 67(3), pp.474-481. DOI: 10.2307/1925976.

Bergstrand, J.H., 1990. The Heckscher-Ohlin-Samuelson Model, the Linder Hypothesis and the Determinants of Bilateral Intra-Industry Trade. The Economic Journal, [e-journal] 100(403), pp.1216-1229. DOI: 10.2307/2233969. 
Bilgin, M.H., Gozgor, G. and Demir, E., 2017. The determinants of Turkey's exports to Islamic countries: The impact of political risks. Journal of International Trade and Economic Development, [e-journal] 27(5), pp.1-18. DOI: 10.1080/09638199. 2017.1396489.

Binh, D.T.T., Duong, N.V. and Cuong, H.M., 2013. Applying Gravity Model to Analyze Trade Activities of Vietnam, [online] Available at: <https://pdfs.semanticscholar.org/ 397e/255fa644b8c2c7500987c634b2315d50aad4.pdf> [Accessed 13 August 2020].

Chaney, T., 2011. The Gravity Equation in International Trade: An Explanation, [online] Available at: <https://www.tse-fr.eu/sites/default/files/medias/doc/by/chaney/ distance.pdf $>$ [Accessed 11 August 2020].

Deardorff, A.V., 1998. Determinants of Bilateral Trade: Does Gravity Work in a Neoclassical World?. In: J.A. Frankel ed., 1998. The Regionalization of the World Economy. S.l.: University of Chicago Press, pp. 7-32

de Groot, H.L.F., Linders, G.-J., Rietveld, P. and Subramanian, U., 2003. The Institutional Determinants of Bilateral Trade Patterns. Tinbergen Institute of Discussion Paper, TI 2003-044/3.

Dollar, D. and Kraay, A., 2004. Trade, Growth and Poverty. The Economic Journal, [ejournal] 114(493), pp. F22-F49. DOI: 10.1111/j.0013-0133.2004.00186.x.

Egger, P., 2002. An Econometric View on the Estimation of Gravity Models and the Calculation of Trade Potentials. The World Economy, [e-journal] 25(2), pp.297-312. https://doi.org/10.1111/1467-9701.00432.

Egger, P.H. and Staub, K.E., 2015. GLM estimation of trade gravity models with fixed effects. Empirical Economics, [e-journal] 50(1), pp. 137-175. DOI: 10.1007/s00181015-0935-x.

Felbermayr, G., Gröschl, J. and Heiland, I., 2018. Undoing Europe in a New Quantitative Trade Model. Ifo Institute - Leibniz Institute for Economic Research at the University of Munich. Ifo Working Paper No. 250.

Gylfason, T., Martínez- Zarzoso, I. and Wijkman, P.M., 2015. Free Trade Agreements, Institutions and the Exports of Eastern Partnership Countries. Journal of Common Market Studies, [e-journal] 53(6), pp.1214-1229. https://doi.org/10.1111/jcms.12275.

Head, K. and Mayer, T., 2014. Gravity Equations: Workhorse, Toolkit, and Cookbook. In: G. Gopinath, E. Helpman and K. Rogoff eds., 2014. Handbook of International Economics. Vol. 4. S.1: Elsevier, pp. 131-195. DOI: 10.1016/B978-0-444-54314-1.00003-3.

Helpman, E. and Krugman, P., 1985. Market Structure and Foreign Trade. Cambridge, MA: MIT Press.

Hufty, M., 2011. Investigating Policy Processes: The Governance Analytical Framework (GAF). In: U. Wiesmann and H. Hurni eds., 2011. Research for Sustainable Development: Foundations, Experiences, and Perspectives. Bern: Geographica Bernensia, pp.403-24.

International Trade Centre, 2020. International Trade Statistics 2001-2020. [online] Available at: <https://www.intracen.org/itc/market-info-tools/trade-statistics/> [Accessed 28 November 2020].

Jansen, M. and Nordås, H.K., 2004. Institutions, Trade Policy and Trade Flows. WTO Staff Working Paper No. ERSD-2004-02. DOI: 10.2139/ssrn.923544. 
Kaufmann, D., Kraay, A. and Zoido-Lobatón, P., 2002. Governance Matters II: Updated indicators for 2000-01. World Bank Policy Research Working Paper, 2772.

Kaufmann, D., Kraay, A. and Mastruzzi, M., 2004. Governance Matters III: Updated indicators for 1996, 1998, 2000, and 2002. World Bank Economic Review, 18, pp.253- 287.

Khorana, S., McGuire, S. and Perdikis, N., 2014. Multilateral Agreements and Global Governance of International Trade Regimes. Scientific Paper FP-7, ATLANTIC FUTURE Project.

Kucharcukova, B.O., Babecky, J. and Raiser, M., 2010. A Gravity approach to Modelling International Trade in South-Eastern Europe and The Commonwealth of Independent States: The Role of Geography, Policy and Institution. CNB Working Paper Series, 1-26.

Linders, G.-J.M., Slangen, A., de Groot, H.L.F. and Beugelsdijk, S., 2005. Cultural and Institutional Determinants of Bilateral Trade Flows. TI 2005-074/3, Tinbergen Institute Discussion Paper.

Linnemann, H., 1966. An econometric study of international trade flows. Amsterdam: North-Holland Publishing Company.

Marimoutou, V., Peguin, D. and Peguin-Feissolle, A., 2010. The "distance-varying" gravity model in international economics: Is the distance an obstacle to trade?. Economics Bulletin, 29(2), pp.1139-1155.

Martínez-Zarzoso, I. and Márquez-Ramos, L., 2019. Exports and governance: Is the Middle East and North Africa region different?. The World Economy, [e-journal] 42(1), pp.143174. https://doi.org/10.1111/twec.12633.

Pöyhönen, P., 1963. A Tentative Model for the Volume of Trade between Countries. Weltwirtschaftliches Archiv, 90(1), pp.93-100.

Pulliainen, K., 1963. A World Trade Study: An Econometric Model of the Pattern of the Commodity Flows in International Trade in 1948-1960. Ekonomiska Samfundets Tidskrift, 16, pp.69-77.

Ranjan, P. and Lee, J.Y., 2007. Contract enforcement and international trade. Economics and Politics, 19, pp.191-218.

Setyastuti, R., Adiningsih, S. and Widodo, T., 2018. The Role of Governance Quality in Increasing Intra-ASEAN Trade. MPRA Paper 85258, University Library of Munich, Germany.

Tinbergen, J., 1962. An Analysis of World Trade Flows. In: J. Tinbergen ed., 1962. Shaping the World Economy. New York, NY: Twentieth Century Fund.

van Bergeijk, P.A.G. and Brakman, S., 2011. The Gravity Model in International Trade: Advances and Applications. S.l: Cambridge University Press. https://doi.org/10.1017/ CBO9780511762109.

Walsh, K., 2006. Trade in Services: Does Gravity Hold? A Gravity Model Approach to Estimating Barriers to Services Trade. IIIS Discussion Paper Series No. 183.

World Bank, 2020. Worldwide Governance Indicators, [online] Available at: <https://databank.worldbank.org/source/worldwide-governance-indicators> [Accessed 26 November 2020]. 